\title{
Food Security Production Challenges in Indonesia as Impact of Global Climate Change
}

\author{
Dani Lukman Hakim ${ }^{1}$, Dedi Herdiansah ${ }^{2}$ \\ ${ }^{1}$ Associate Professor, Faculty of Agriculture, Galuh University \\ ${ }^{2}$ Lecturer, Faculty of Agriculture, Galuh University
}

\begin{abstract}
Global food availability, including national as well as local, is highly dependent on the natural resources that will affect crop production. Although there is rain, soil temperatures and conditions have formed a natural system that will support agricultural efforts, but this state is unstable and always changes according to atmospheric conditions in an integrated manner. Human beings on certain boundaries can intervene with the natural resources.
\end{abstract}

Climate (generally a combination of rain, temperature, and sunlight) is the most important growth factor in crop production in the field. Any change in climatic conditions will have far-reaching effects on global food production.

Global climate change, excessive land and land exploitation, inaccurate land management, in its time will have an impact on the food production and availability of a region. Knowing well the of nature characteristics, then anticipating the impact that will arise and determine the ways of handling it, is a series of business and activities that must be done to achieve food security.

To anticipate climate change and its impacts on crop production, a broad outline can be made by considering the following physical technic aspects: 1) adjusting cropping patterns; 2) increasing the area of forest cover and catchment areas; 3) application of land and crop management technology. Some application of land and crop management technologies include: organic farming, implementation of Surjan system, food diversification, large tree planting, water pond production, etc.

The policies that need to be taken as a solution in anticipating the impact of global climate change are 1) the preparation and stipulation of special food agriculture scenarios, including the zoning of production potential and zonation of climate risk (drought, flood, landslide, etc.) with the updating of data every year; 2) reducing the conversion of agricultural land (food); 3) incentives for farmers; 4) changing the consumption pattern of the people, from the consumption of rice to alternative staple foods; 5) subsidies and protection of food farming; 6) climate monitoring and prediction (early rainy season, long growing period, and potential water availability; 7) Revitalization of watershed (DAS) functions; 8) Multiply the artificial water absorption area.

Keywords - Climate Change, Food Security, Land and Crop Management, Watershed.

\section{INTRODUCTION}

Increased concentrations of greenhouse gases in the atmosphere due to human activities around of the world, causing increased radiation trapped in the atmosphere. The impact is the occurrence of an increase in average temperatures across the earth's surface, referred to as global warming.

Increasing the average temperature of the Earth's surface causes changes in other climatic elements, such as rising sea temperatures, increased evaporation in the air, and changing patterns of rainfall and air pressure that eventually change the pattern of world climate. This event became known as global climate change.

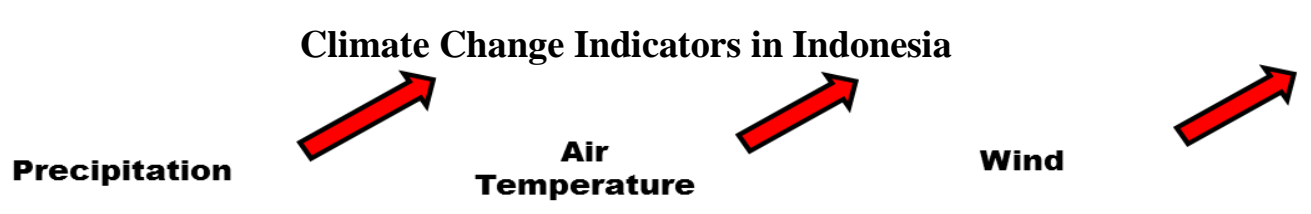


TABLE 1

Climate Change INDICATORS IN INDONESIA

\begin{tabular}{|c|c|c|c|}
\hline No. & Climate Elements & Phenomenon & Impact \\
\hline 1. & Precipitation & Longer dry season & Water shortage, crop failure \\
\hline & & Shorter rainy season with high intensity & Flood, erosion, landslide, crop failure \\
\hline 2. & Air Temperature & The temperature is hotter & Increased evaporation, impaired growth \\
\hline 3. & Wind & Strong local winds at the time of the rain & Disrupting plant growth \\
\hline
\end{tabular}

\section{Global Climate Change Indicators}

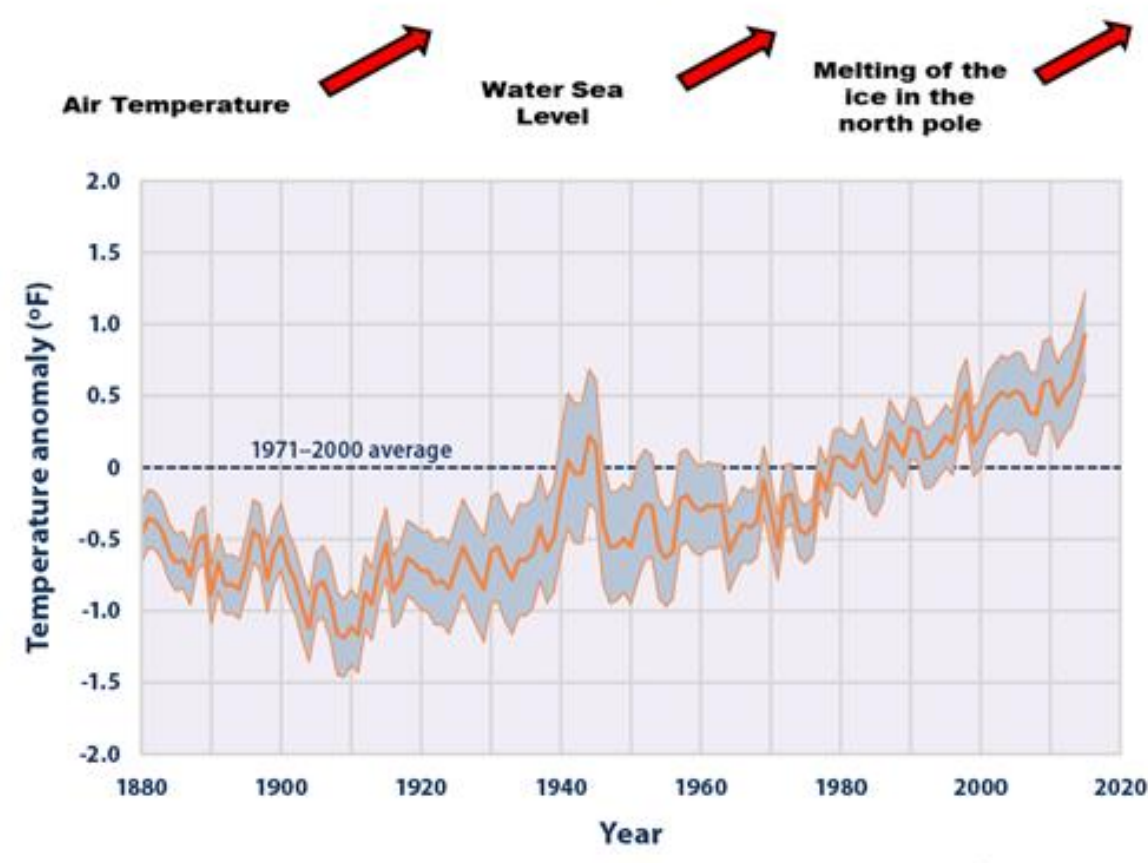

Data source: NOMA National Oceanic and Atmospheric Administrationi. 2016. Extended reconstructed sea surface temperature (ERSST.v4). National Centers for Environmental Information. Accessed March 2016.

Figure 1. AVerage Global Sea Surface Temperature, 1880-2015

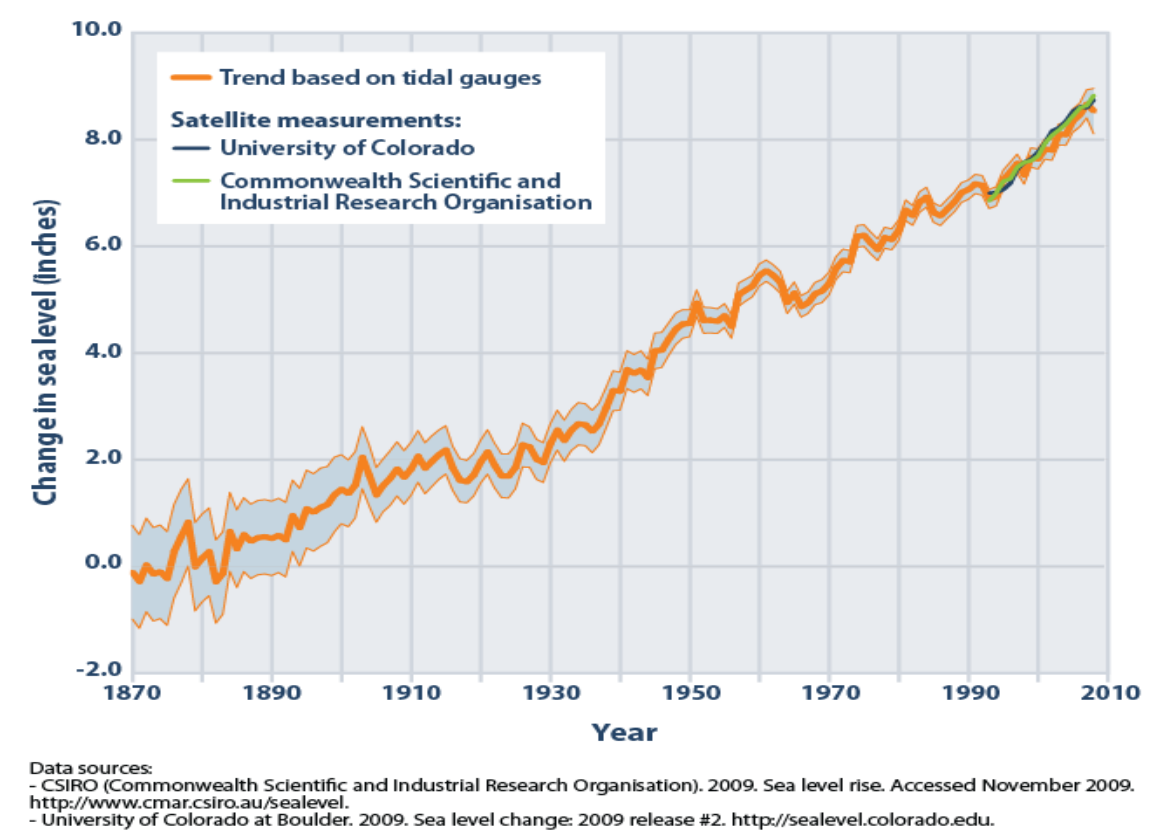

Figure 2. Trends in Global AVERAge AbSOLUTE SEA LEVEL, 1870-2008 


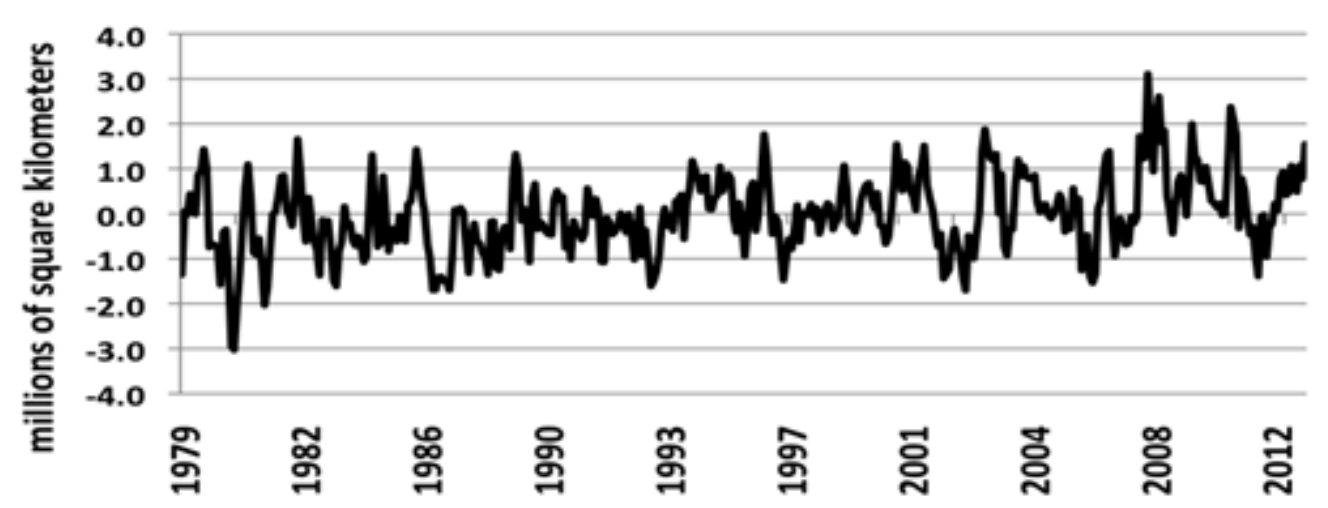

FIGURE 3. ANTARTIC SEA ICE EXTENT ANOMALIES, 1979-2012 (UNIVERSITY OF ILLINOIS)

\section{DATA AND FACT}

At the regional micro-scale in Indonesia, several climate elements that undergo changes include wind, temperature, and precipitation (Table 2).

Some studies of average historical data, air temperatures in Indonesia increased by $0.3{ }^{\circ} \mathrm{C}$ per year since 1900 . in the $1990 \mathrm{~s}$ was the warmest decade and 1998 was the warmest year, $1{ }^{\circ} \mathrm{C}$ above the 1961-1990 average. Increased temperatures occur throughout the season. Rainfall is reduced by 2 to $3 \%$ especially in December-February. In most parts of Indonesia rainfall is affected by El-Nino, major droughts occur in El-Nino years 1982/1983, 1986/1987, and 1997/1998.

TABLE 2

The Changing of Climate Elements IN INDONESIA

\begin{tabular}{|c|c|c|c|c|}
\hline \multirow{2}{*}{ Location } & \multirow{2}{*}{ Year } & \multicolumn{3}{|c|}{ The Changing Element per Year } \\
\cline { 3 - 5 } & & Temperature & $\begin{array}{c}\text { Precipitation (dry } \\
\text { season) }\end{array}$ & $\begin{array}{c}\text { Precipitation (wet } \\
\text { season) }\end{array}$ \\
\hline Data Source 1 & & & $*$ & $*$ \\
\hline Jakarta & $1916-1987$ & $0.03 * *$ & $-0.1 \%$ & $10 \% * *$ \\
\hline Jakarta & $1951-1987$ & $*$ & $-1.1 \% * *$ & $0.3 \%$ \\
\hline Bogor & $1951-1987$ & $*$ & $*$ & $*$ \\
\hline *Bogor & $1976-1987$ & $0.05 * *$ & $-2.0 \% * *$ & $4.6 \% * *$ \\
\hline Bogor & $1980-1998$ & $0.14 * *$ & & \\
\hline Data Source 2 & & & Hujan tahunan menurun $2-3 \%$ \\
\hline Indonesia & & Meningkat $0.3^{\circ} \mathrm{C}$ & & \\
\hline
\end{tabular}

Data Source 1: Hidayati (1990), Hidayati, Abdullah, and Suharsono (1999).

Data Source 2: Hulme and Sheard (1999), Boer and Faqih (2004).

TABLE 3

The Changing OF MONTHLy Rainfall ON NORMAL RAINFALl (IN \%, AVERAGE VALUE 1970-1997 IN SOME PROVINCE)

\begin{tabular}{|c|c|c|c|c|c|c|}
\hline \multirow[b]{2}{*}{ Island } & \multicolumn{3}{|c|}{1970} & \multicolumn{3}{|c|}{1997} \\
\hline & $\begin{array}{c}\text { Oct-Mar or } \\
\text { Nov-Apr }\end{array}$ & $\begin{array}{c}\text { Apr-Sept or } \\
\text { May-Oct }\end{array}$ & Annual & $\begin{array}{c}\text { Oct-Mar or } \\
\text { Nov-Apr }\end{array}$ & $\begin{array}{c}\text { Apr-Sept or } \\
\text { May-Oct }\end{array}$ & Annual \\
\hline Sumatera & -35 & -47 & -38 & -21 & -32 & -24 \\
\hline Java & -34 & -80 & -41 & -11 & -85 & -23 \\
\hline Bali/NTT & -26 & -82 & -31 & -26 & -75 & -32 \\
\hline Kalimantan & -33 & -57 & -40 & -5 & -36 & -16 \\
\hline Sulawesi & -28 & -67 & -39 & -35 & -33 & -30 \\
\hline Maluku/Ambon & -13 & -53 & -40 & -5 & -27 & -20 \\
\hline Indonesia & -32 & -62 & -38 & -19 & -47 & -24 \\
\hline
\end{tabular}

\section{Data Source: Irawan, 2002}

\section{MATERIALS AND METHOD}

The methodology used in this research is the Sytematic Review Method. As with the methodology of individual research, in principle, systematic review research begins by making a systematic review research protocol and the next stage of 
conducting systematic review research. Sequentially, the process of systematic review research is shown in Table 4. Analog with general research methodology, where there are quantitative and qualitative methods, then in systematic review there are also quantitative methods and qualitative methods.

Quantitative method of systematic review is used to synthesize the results of research with quantitative approach. For example, Randomized Control Trials (RCTs), Cohort Study, Case-Control Study, or prevalence studies. The statistical approach in synthesizing the results of quantitative research is called "meta-analysis". By definition, meta-analysis is a technique of aggregating data to obtain statistical power in identifying causal relationships between risk factors or treatment with an outcome (Perry \& Hammond, 2002). Meanwhile, qualitative approach in systematic review is used to synthesize qualitative descriptive research results. The method of synthesizing (summarizing) the results of qualitative research is called "meta-synthesis". By definition, meta-synthesis is a technique of integrating data to gain new theories and concepts or deeper and more thorough understanding levels (Perry \& Hammond, 2002).

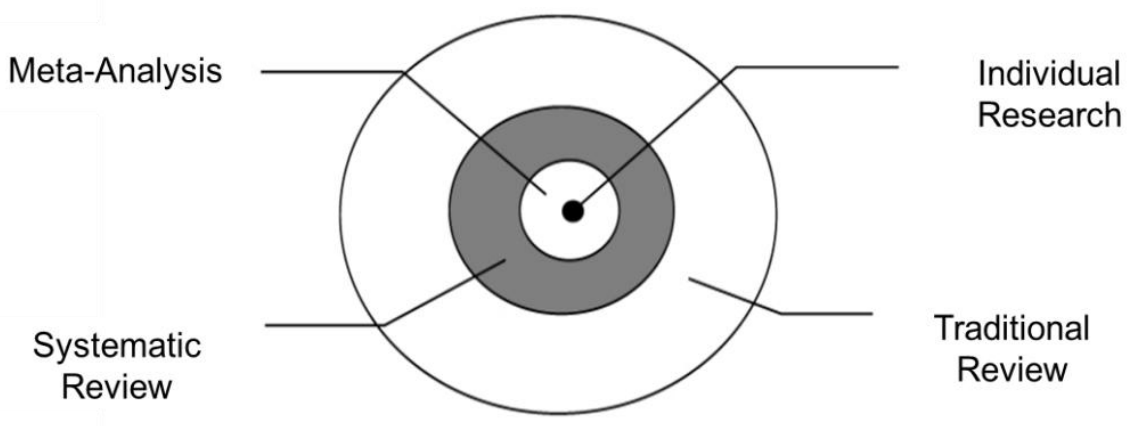

Figure 4. Position of Systematic Review Methods in ANOther ReSEarch Methods

TABLE 4

Sequence of Systematic Review Process (Perry \& Hammond, 2002)

\begin{tabular}{|c|c|c|}
\hline No. & Sequence of Process & Objective \\
\hline 1. & Identify questions research & $\begin{array}{c}\text { Make a transformation climate change problems into } \\
\text { question research }\end{array}$ \\
\hline 2. & Develop protocol research systematic review & Giving guides in doing systematic review \\
\hline 3. & Set location Data-base results research as search area & $\begin{array}{c}\text { Provide restrictions search area against the results of } \\
\text { the study which is relevant }\end{array}$ \\
\hline 4. & Selection of results relevant research & $\begin{array}{c}\text { Collect the results relevant research with questions } \\
\text { research }\end{array}$ \\
\hline 5. & Select good quality results of research & $\begin{array}{c}\text { Conducting exclusion and inclusion of research to be } \\
\text { entered in systematic review based on quality }\end{array}$ \\
\hline 6. & Data extraction from individual studies & $\begin{array}{c}\text { Perform data extraction from individual studies to get } \\
\text { the findings importance }\end{array}$ \\
\hline 7. & Result synthesis by method Meta-analysis (if allow), \\
or & narrative method (if impossible) & $\begin{array}{c}\text { Conducting synthesis of results with metaanalysis } \\
\text { techniques (forest plot) or narrative techniques } \\
\text { (metasintesis) }\end{array}$ \\
\hline 8. & Presentation of results & $\begin{array}{c}\text { Write down the results research in the document } \\
\text { reports systematic results review }\end{array}$ \\
\hline
\end{tabular}

\section{RESULTS AND DISCUSSION}

\subsection{Impact of Climate Change}

\subsubsection{Floods and Drought}

Indonesia there have been 46 major drought events, 30 of which occurred in the period 1844-1960 (for 117 years), and the remaining 16 events in the period 1961-2006 (only for 46 years). While the floods, became a common occurrence almost every rainy season in various provinces (Ministry of Environment Republic of Indonesia, 2007). During the period of 20012004 there have been 530 flood events in various regions in Indonesia. 


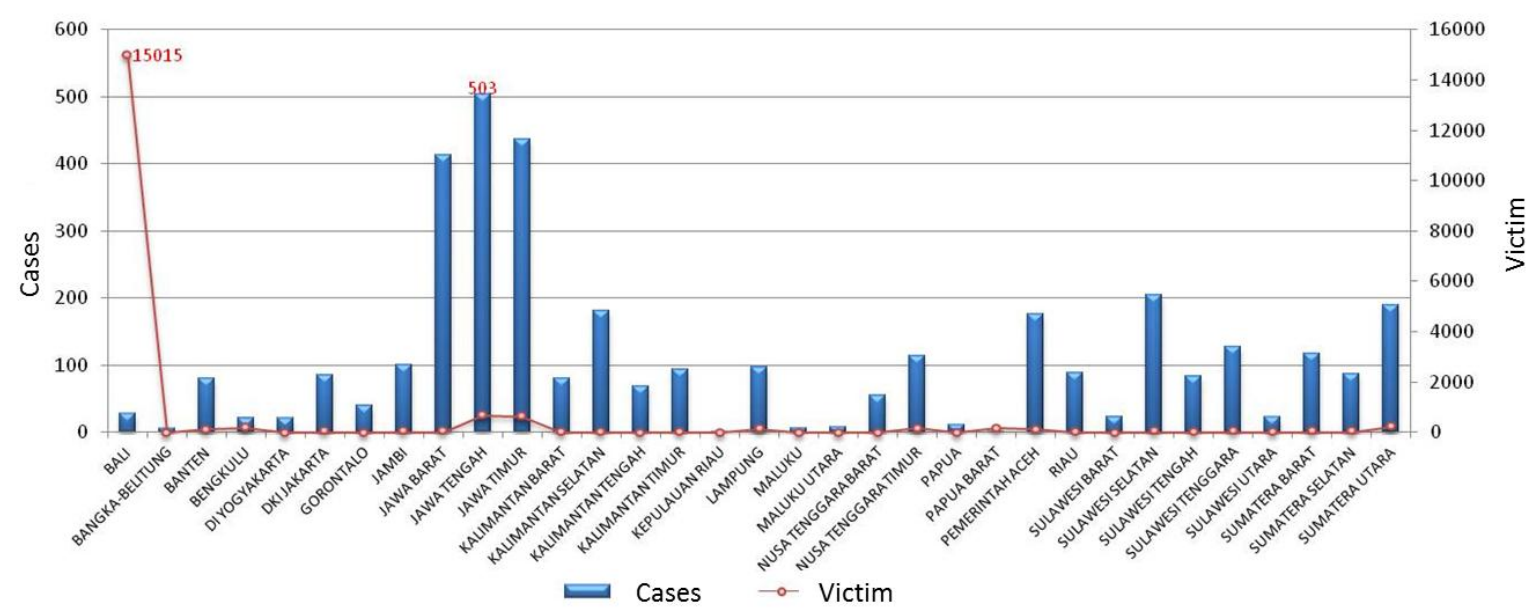

Figure 5. Number of FloOd CaSeS ANd Victims Deaths Per Province 1822-2011 (Data SourCe BNPB, 2012)

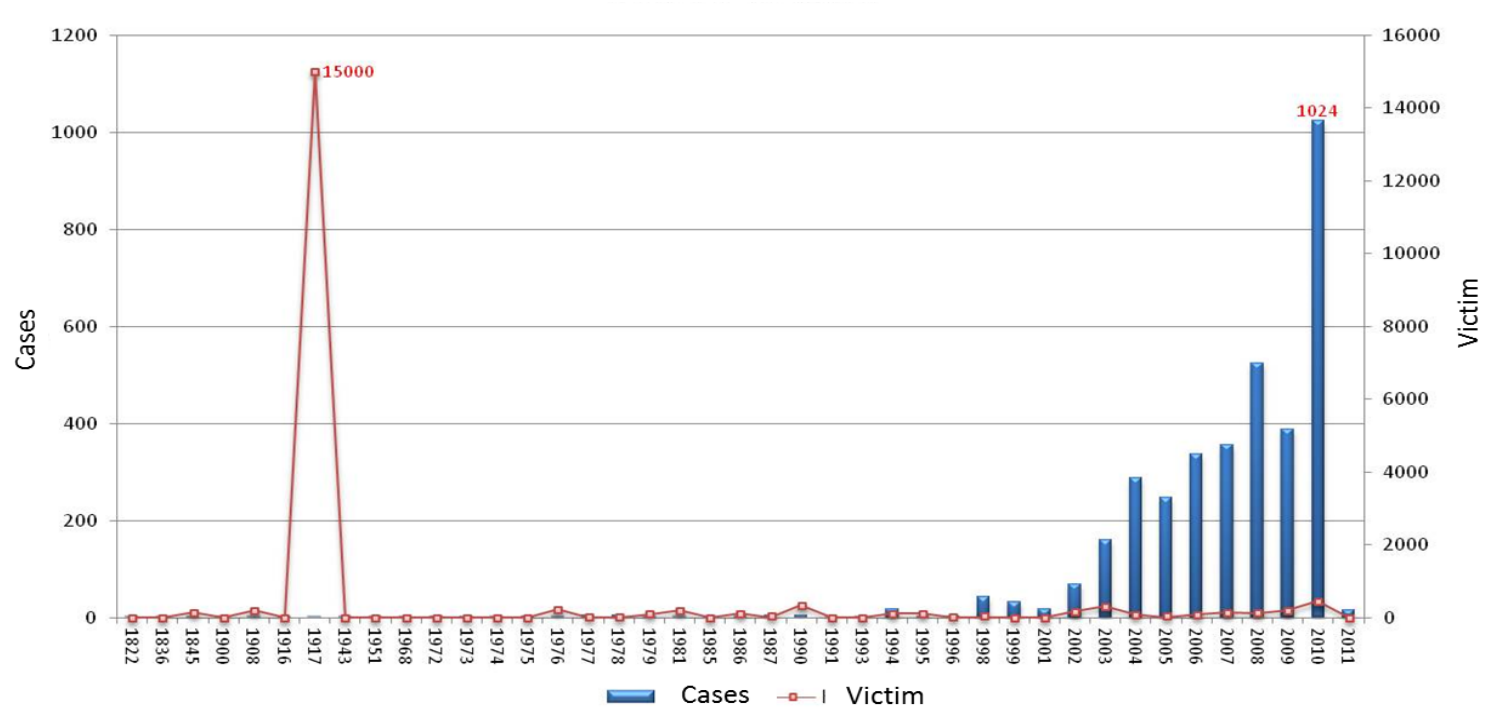

Figure 6. Number Of FloOd CASES ANd Victims Deaths PER Year 1822-2011, (DATA SOURCE BNPB, 2012)

TABLE 5

SITUATION OF DROUGHT AND HARVEST FAILURE IN INDONESIA

\begin{tabular}{|c|c|c|}
\hline Year & $\begin{array}{c}\text { Drought Impact (Decreasing } \\
\text { Production in Hectares) }\end{array}$ & Harvest Failure in Hectares \\
\hline $\mathbf{1 9 9 0 s}$ & & 489,178 \\
\hline 1994 & 18,462 & 150,319 \\
\hline 1995 & 48,490 & 3,385 \\
\hline 1996 & $\mathbf{5 5 6 , 1 3 0}$ & $\mathbf{1 6 5 , 1 6 2}$ \\
\hline Total & & 11,344 \\
\hline $\mathbf{2 0 0 0 s}$ & 145,545 & 30,694 \\
\hline 2001 & 298,678 & 82,690 \\
\hline 2002 & 430,258 & $\mathbf{1 2 4 , 7 2 8}$ \\
\hline 2003 & $\mathbf{8 7 4 , 4 8 1}$ & \\
\hline Total &
\end{tabular}

Data Source : Indonesian Department of Agriculture, 2007. 


\section{TABLE 6}

CONDITION OF WATERSHED (DAS) IN JAVA ISLAND

\begin{tabular}{|c|c|c|c|c|c|c|c|}
\hline No. & Province & Broodstock & $\begin{array}{c}\text { DAS } \\
\text { Square } \\
\left(\mathbf{K m}^{2}\right)\end{array}$ & Min & Max & Qmax/Qmin & Condition \\
\hline 1. & Banten & S. Ciujung & 1,563 & 1.0 & 1,880 & 1,880 & Critical \\
\hline 2. & West Java & S. Cisadane & 820 & 1.0 & 1,150 & 1,150 & Critical \\
\hline & & S. Ciliwung & 158 & 0.1 & 390 & 3,900 & Critical \\
\hline & & S. Citarum & 1,675 & 2.0 & 370 & 185 & Critical \\
\hline & & S. Cimanuk & 1,966 & 1.0 & 710 & 710 & Critical \\
\hline & & S. Citanduy & 1,416 & 0.1 & 1,250 & 12,500 & Critical \\
\hline 3. & Central Java & K. Pemali & 856 & 0.1 & 850 & 8,500 & Critical \\
\hline & & K. Serang & 98 & 0.1 & 100 & 1000 & Critical \\
\hline & & K. Juana & 46 & 0.1 & 110 & 1,100 & Critical \\
\hline & & B. Solo & 3,207 & 2.0 & 9,990 & 4,495 & Critical \\
\hline & & K. Serayu & 723 & 3.0 & 1,580 & 527 & Critical \\
\hline 4. & DIY & K. Progo & 423 & 0.1 & 900 & 9,000 & Critical \\
\hline & & K. Opak & 30 & 0.1 & 10 & 100 & Critical \\
\hline 5. & East Java & K. Brantas & 7,112 & 10.0 & 3,180 & 316 & Critical \\
\hline & & K. Sampean & 612 & 0.1 & 850 & 8,500 & Critical \\
\hline & & K. Pekalen & 163 & 0.1 & 200 & 2000 & Critical \\
\hline
\end{tabular}

Data Source : DBPSDA-PU, 2009.

\subsubsection{Agriculture Production (Paddy)}

Notes in the Indonesian Meteorological and Geophysical Agency show that the dry periods Indonesia has experienced are 1991, 1993, 1994, 1997, 2000, and 2001, while the times of excess water are 1992, 1996, 1999, and possibly 2002 (Table 5). This fact can be used to predict and simultaneously inform not only when the right planting, but also the type of plant that best fits the condition. This will greatly assist food security efforts and reduce the risk of crop failure.

\section{TABLE 7}

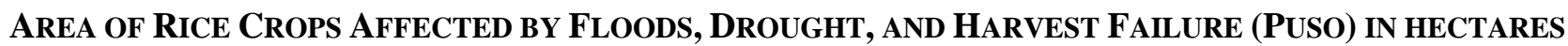
(1988-1997)

\begin{tabular}{|c|c|c|c|c|}
\hline Year & Remark & Flood & Drought & Puso \\
\hline 1987 & El-Nino & $* * *$ & 430,170 & $4 *, 049$ \\
\hline 1988 & La-Nina & 130,375 & 87,373 & 15,290 \\
\hline 1989 & Normal & 96,540 & 36,143 & 19,163 \\
\hline 1990 & Normal & 66,901 & 54,125 & 198,054 \\
\hline 1991 & El-Nino & 38,006 & 867,997 & 16,882 \\
\hline 1992 & Normal & 50,360 & 42,409 & 47,259 \\
\hline 1993 & Normal & 78,480 & 66,992 & 194,025 \\
\hline 1994 & El-Nino & 132,975 & 544,422 & 51,571 \\
\hline 1995 & La-Nina & 218,144 & 28,580 & 50,649 \\
\hline 1996 & Normal & 107,385 & 59,560 & 102,254 \\
\hline 1997 & El-Nino & 58,974 & 504,021 & \\
\hline
\end{tabular}

Data Source : Jasis and Karama, 1999; Yusmin, 2000. 


\subsection{Projection of Food Production}

The effect of climate change on crop production depends on factors, namely: 1) the magnitude of changes in influencing climate variables; and 2) plant adaptability. According to Rosenzwig and Iglesias (IPCC, 1996), there will be a decline in some food commodities in some countries as follows (Table 8). The most influential aspects of climate elements to production are air temperatures and rain.

\section{TABLE 8}

PREDICTION OF FoOd PRODUCTION IN SOME COUNTRIES

\begin{tabular}{|c|c|}
\hline Countries & Impact to Agriculture Production \\
\hline Indonesia & Rice $-2.5 \%$; Soybean $-2.3 \%$; Maize $-40 \%$ \\
\hline Malaysia & Rice $-22 \%$ to $-12 \% ;$ Rubber $-30 \%$ to $-3 \%$ \\
\hline UK & Land Productivity $(+5 \%$ to $+15 \%)$ \\
\hline USA & Wheat $-14 \%$ to $-2 \% ;$ Maize $-29 \%$ to $-15 \% ;$ rice $-23 \%$ \\
\hline
\end{tabular}

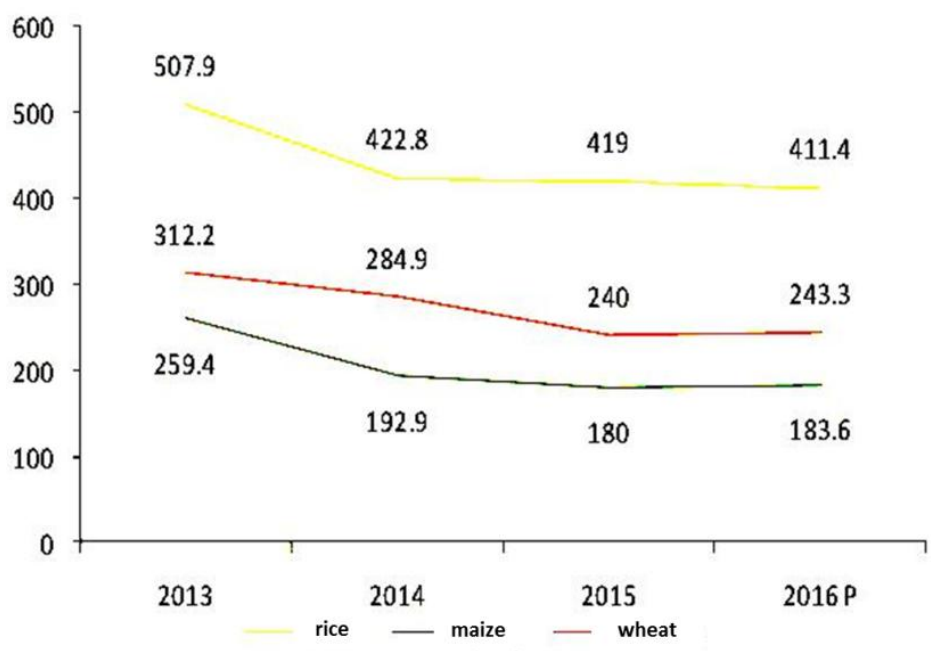

\section{Figure 7. Projection Of Global Food Production DeCrease (Data Source IGICo AdVisory, 2015)}

\subsection{Adaptation and Mitigation}

To anticipate climate change and its impact on crop production, the outline can be done by considering the following physical technic aspects:

1. Adjusting cropping patterns;

2. Increasing the area of forest cover and catchment areas;

3. Application of land and crop management technology. Some application of land and crop management technologies include: organic farming, implementation of Surjan system, food diversification, large tree planting, water pond production, etc.

\section{CONCLUSION}

The policies that need to be taken as a solution in anticipating the impact of global climate change are:

1. The preparation and stipulation of special food agriculture scenarios, including the zoning of production potential and zonation of climate risk (drought, flood, landslide, etc.) with the updating of data every year;

2. Reducing the conversion of agricultural land (food);

3. Incentives for farmers; 
4. Changing the consumption pattern of the people, from the consumption of rice to alternative staple foods;

5. Subsidies and protection of food farming;

6. Climate monitoring and prediction (early rainy season, long growing period, and potential water availability.

7. Revitalization of watershed (DAS) functions.

8. Multiply the artificial water absorption area.

\section{REFERENCES}

[1] Badan Penelitian dan Pengembangan Pertanian. 2005. Prospek dan Arah Pengembangan Agribisnis: Tinjauan Aspek Kesesuaian Lahan. Departmen Pertanian RI. Jakarta.

[2] Direktorat Jenderal Tanaman Pangan. 2009. Forum Rapat Tematik Pusat Sumber Daya Alam Darat Bakosurtanal - "Neraca Komoditas Pangan dan Perkebunan Beserta Data Pendukungnya". Bandung 23 Juni 2009.

[3] FAO. 2007. Adaptation to Cimate Change in Agriculture, Forestry, and Fisheries: Prespective, Framework, and Priorities. FAO InterDepartmental Working Group on Climate Change. Rome. Italy.

[4] Hidayati, Rini. 2001. Masalah Perubahan Iklim di Indonesia. Beberapa Contoh Kasus. Makalah Falsafah Sains (PPs 702) Program Pascasarjana/S3 Institut Pertanian Bogor.

[5] Hidayati, R., Abdullah, S.E.A., dan Suharsono, H. 1999. Perubahan Iklim di Bogor (Studi Kasus 5 Kecamatan) hubungannya dengan perubahan pemanfaatan lahan. Makalah pada Simposium Internasional PERHIMPI. Bogor 18-20 Oktober 1999.

[6] Hidayati, R. 1990. Kajian Iklim Kota Jakarta, Perubahan dan Perbedaan dengan Daerah Sekitarnya. Tesis Program Studi Agroklimatologi. FPS-Institut Pertanian Bogor.

[7] Irawan, B. 2002. Stabilization of Upland Agriculture under Al-Nino-Induced Climatic Risk: Impact Assesment and Mitigation Measures in Indonesia. Centre for Research and Development of Coarse Grain, Pulses, Roots, and Tuber Crops in Humid Tropics of Asia and Pacific (CGPRT Centre). Working Paper No.62.

[8] Meiviana, Armely., Diah R Sulistiowati, dan Moekti H Soejachmoen. 2004. Bumi Makin Panas. Ancaman Perubahan Iklim di Indonesia. Kementrian Lingkungan Hidup Republik Indonesia dan Pelangi (Yayasan Pelangi Indonesia). Jakarta.

[9] MoE. 2007. Indonesia Country Report: Climate Variability and Climate Change, and Their Implication. Ministry of Environment, Republic of Indonesia. Jakarta.

[10] Perry, A. \& Hammond, N. (2002). Systematic Review: The Experience of a PhD Student. Psychology Learning and Teaching, 2(1), 32-35.

[11] Siswanto. 2017. Systematic Review Sebagai Metode Penelitian Untuk Mensintesis Hasil-Hasil Penelitian (Sebuah Pengantar). Pusat Penelitian dan Pengembangan Sistem dan Kebijakan Kesehatan, Badan Litbang Kesehatan, Kementerian Kesehatan. Jakarta. 